\title{
Straddling For Market Space: Transforming Estonian State-Owned Enterprises Toward A Free-Market Orientation
}

\author{
Timo J. Santalainen (E-mail: santalainen@ stratnet.inet.fi), Helsinki School of Economics and STRATNET, Finland \\ Ram B. Baliga, Wake Forest University \\ Jaak Leimann (E-mail: leimann@tv.ttu.ee), Tallinn Technical University, Estonia
}

\begin{abstract}
This paper examines the dynamics of transformation of three Estonian state-owned enterprises Eesti Gaas, Eesti Energia and Eesti Telefon - toward a free market orientation following the Estonia's decision to separate from the USSR. The difficulties of such transformation are first examined from a theoretical perspective. It is argued that organizations attempting such transformation are likely to be stuck in a state of dynamic equilibrium between the old static mode and the emerging free-market mode until some key factor causes it to tip over into one or the other of these modes. Four major transformational challenges - strategic orientation, resource and competency acquisition logic, workforce and organizational configuration - are discussed by examining the dynamics of transformation of three Estonian state-owned enterprises.
\end{abstract}

\subsection{Introduction}

$T$

he resurgence of the market model of economic functioning in Eastern and Central Europe and Asia has generated a process of transformation with many formerly state-controlled enterprises in the process of being privatised or corporatised. Corporatisation and moving toward a market economy are seen as solutions to the problems caused by decades of communism/socialism/central planning. Although the pace of transformation has varied across countries, these changes have been real jolts to the organisations, institutions and governments involved.

In the course of this transformation, global institutions such as the IMF and the World Bank have placed significant pressures on governments and firms in liberalising countries that they adopt Western models, particularly the US model, of management and governance. Strong assertions have been made that failure to do so would doom these organisations and their home countries to failure in the global economy.

What does the adoption of a U.S. model of management imply? Fundamentally, it requires firms to wean themselves off from state subsidies, increase productivity through workforce reductions, tighten managerial control, and, in general, strive to maximise enterprise and shareholder value (Child and Markoczy, 1994; Hitchens et al., 1995). Despite these explicit pressures for adoption of the US model, recent studies have found that the macro-level efforts at liberalisation have, often, not led to called-for, radical changes in organisational functioning (Burawoy and Lukacs, 1992; Whitley et al. 1996). While some organisations have found it difficult to mobilise the necessary resources to facilitate the transformation (Pearce, 1991), even those with substantial resources, financial and otherwise, have found the transformation processes rough going. The prevailing pattern appears to be one of oscillating between their "historic" management model/configuration and the recommended Western one occasionally reaching a configuration of dynamic equilibrium, a configuration we label as parastatal. The organisation stays in this state of suspended animation till something causes it to tip in one direction or the other; however, the organisation that emerges fails to either move to its original configuration or a "true U.S. model".

Readers with comments or questions are encouraged to contact the authors via email. 
Rather it generally appears as a hybrid that takes into account the particular social, political and cultural contexts in which the transformation is taking shape. This paper examines first from a theoretical perspective the issues involved in making such transformations. We then describe, briefly, the privatisation of the Estonian economy and then proceed to test our perspective by examining in detail the transformation efforts of three Estonian firms.

\subsection{Transformational Challenges}

Much prior work in the area of transformational change was girded by assumptions of rationality and linear thinking. Scholars assumed that new models or paradigms of organisational functioning could be implemented in an institutional vacuum and the role played by administrative heritage (Bartlett and Ghoshal, 2000) was either overlooked or de-emphasised. It is our position that given the dramatic pressures emanating from their macro- and micro-environments, the overarching challenge confronting firms undergoing transformation is dealing with secondorder or frame-breaking change (Meyer, Brooks and Goes, 1990; Argyris and Schoen, 1978). Specifically, challenges are posed in the following areas:

1. Strategic Orientation - How to break away from the statist archetype - where the role of the organisation in the overall economy and society was established from above - and move toward the more 'business like' archetype by establishing a new mission, strategic intent and creating a comprehensive business model to succeed in market space? Fundamentally, the challenge is to abandon the old "What?" "How?" and "For whom?"

2. Resource and Competency-acquisition logic - How to justify the need for interim 'state' support as it moves to drawing upon resources in open markets? How to acquire reaources and competencies through partnering? How to acquire the set of competencies that are appropriate for competing in emerging market space?

3. Workforce - How to maintain morale in the current workforce even as it seeks to attract employees whose mind set, values and competencies are consistent with those necessary for operating in free/open market sectors?

4. Organisational Configuration - How to develop organisational structures and processes that are appropriate for functioning in 'market-space' rather than 'centrally planned-space'? How to build and work with an external value network?

We examine these challenges in greater detail below.

\subsection{Strategic Orientation}

In a nutshell, given that it is impossible to shut down functioning organisations and start anew, the fundamental transformational challenge for leaders is to simultaneously manage continuity and divergent change, i.e. abandon an institutionalised template of functioning and replace it with a substantially different one (Clarke, 1994). Organisations confronted with divergent change are forced to transform not only their organisational goals but also widely held beliefs and norms. In the case of organisations in countries that are moving toward a market based economy from a centrally planned one the fundamental challenge is to break up the link between the managerial ideologies and the political order - a link that sets limits to the repertoire of organisational approaches that are either possible or necessary and severely constrains the choice of alternatives by managers and firms. In a nutshell, this challenge manifests itself in developing strategies and business models based on industry logic, technical and economic forces appropriate to the changing environment after decades of being infused with and dominated by non-market based political ideologies. Managers have used these ideologies to inform perception and foster the interests of the "ruling" elite, the nomenklatura.

Institutional theory argues that transformation of such organisations is particularly difficult because of system inertia (Kelly and Amburgey, 1991; Powell and DiMaggio, 1991). This results in organisations clinging to outmoded strategic orientations long after they are appropriate (Best, 1990; Lazonick, 1991; (Lazonick and West 1995). Indeed Lant \& Montgomery (1987) assert that, because the consequences of changing are less well known than the consequences of not changing - with failure now being a realistic possibility - organisations are more apt to distort data to provide rationale for persisting with business as usual. In addition these managers are not comfortable 
with the new market-space ideology. There is tension between the new and established ideologies and because the implications of the established are well known it is easy to revert to it under even the tiniest pretext.

Another reason for the difficulty in acceding to transformational demands could be that such acquiescence would lead to the disruption of stable patterns of activities, processes and competencies (Tushman and Romanelli, 1987) and their replacement by new ones. During long periods of state support or working within the framework of a multitude of objectives that go beyond maximising shareholder value (employment generation or culturally based ones such as providing employment to friends and relatives) these organisations had developed organisational routines (Nelson and Winter, 1982) and institutionalised norms and values (Dimaggio and Powell, 1983) that are unsuited for the demands of the new environment. Organisational leaders had developed sensing mechanisms and political networks to detect and respond to the direction in which the political wind was blowing. Clearly many of these embedded norms, routines, and networks anchored in managing the political process, or, dealing with a nonmarket performance oriented workforce are unsuited to the demands of the new environment. Rather than acknowledging and dealing with these many parastatals choose, instead, to resist second-order or frame breaking innovations (Argyris and Schoen, 1978) by filtering information through a mindset that favours the familiar and well-established operating paradigm (Bettis and Prahalad, 1995). This in turn generally results in managers enacting their old scripts repeatedly and thoughtlessly (Amburgey et al. 1983). Research by Ocasio $(1994,1997)$ has shown that if the top management group is very cohesive they will continue enacting their traditional scripts despite poor performance. In other instances, given the unfamiliar and thus uncertain situation that these organisations are thrown in, managers often resort to imitating the behaviour of other organisations, foreign or domestic, that they perceive as being successful. Such mimetic behaviour is undertaken with little or no concern for the competencies needed to make them truly successful. As a result only superficial transformation takes place despite the conviction of many managers that their organisations have been "transformed". In most instances such "transformation" is characterised by the introduction of market-space jargon and a set of techniques without any substantial transformation taking place in the underlying managerial ideology, a change we think is essential to "deep" transformation.

Given this situation, how does one create deep transformation? Proponents of transformational leadership (Bass, et al., 1987; Hunt and Baliga, 1988) and the "strategic choice' perspective (Child, 1972) argue that only a change in leadership will facilitate organisational transformation. While a change in leadership does, in theory, increase the probability of introduction of a 'newer' script/routine or paradigm this is so, if and only if, the incoming leader or leadership group has ideological commitment to the market space (individual success is not considered "dirty", making money/profits is not exploitation of the proletariat etc.), and the necessary competencies to execute that commitment. In the case of socialist and communist economies undergoing transformation this invariably requires "importing" leaders with the necessary ideology and competencies from the outside. Very often these leaders employ displacement strategies of perversity, jeopardy and futility suggested by Hirschman (1991) with perversity (the current ideology has created results opposite to those that were intended, i.e. rather than improving the quality of life for organisational members it had led to a reduction) being the dominant one. This raises the issue of whether deep transformation can proceed if and only if there is a change in ideology at the outset. Guillen (2001) argues that ideological displacement could take place through the introduction of techniques and processes that are appropriate for functioning in market space. The displacement process could commence by creating two compelling visions: (1) a stretch vision of organisational future girded by a clear strategic intent and (2) an internal vision that offers a measure of long-term security and lays out growth and developmental possibilities for organisational members to move into market space.

Ironically, the importation of foreign managers generally compounds the transformational problem. Organisational members who are uncomfortable with transformation could use the presence of "foreign" investors and managers to rally opponents of the transformation process. Very often this translates into accusations of selling out to foreigners and sacrificing the interests of the public at the altar of free markets, i.e. maximising enterprise and shareholder value at the expense of "social benefits". Clearly such reactions reflect a deep-rooted desire to revert to the established ideology with its accompanying blanket of security. 


\subsection{Resource Acquisition Logic}

Under the statist archetype financial resources were guaranteed from the public exchequer, grants and donations, or membership fees. There were expectations of great social benefits - facilitating industrial development, increasing literacy, improving health and the quality of life, for example - in funding these organisations. Organisational success was very much based on manger's understanding of the right buttons to push in order to gain resources from the state and position his organisation as being pivotal to societal interests. Under the free-market archetype this approach no longer guarantees funding with organisations expected to generate their own funds by offering products and services that are attractive to consumers. Though a period of transition from public funding to private funding is acknowledged, most statist archetype managers would argue that neither this period nor the funds provided are sufficient. Very often they adopt strategic postures to strengthen public resource flows and lengthen the period of support. A very common approach is to assert that there is great reluctance on the part of most customers to pay market prices for products or services that were either totally free or were heavily subsidised in the past and/or argue that public support is needed during a period of transition when the organisation can develop capabilities to produce goods and services with quality levels and value propositions introduced by their competitors from free market economies. As China moves toward a market economy such assertions by managers of stateowned enterprises slated for privatisation has generated a disguised form of public subsidy with funds being provided by state banks, often without any economic rationale or justification. The hijacking of a substantial proportion of industrial capacity in the former Soviet Union by the oligarchs (Kokh, 1998) owing to a weak legal and institutional framework is another example - albeit strong armed - of securing resources from the state in an advantageous manner. In India where the legal and institutional framework is reasonably strong it has been more difficult to raise resources by strong-arm means. In these circumstances the firm managers have sought to build up a constituency of opponents (employees, bureaucrats who were significant gatekeepers to strategic decisions such as capacity expansion, diversification etc.) to delay movement toward the market model and secure additional resources. A recent example of such actions has been the effective scuttling of the privatisation of Air India. Forced to keep Air India viable, even as it develops a new strategy of privatisation, the government has been forced to funnel additional resources into the entity (McMillen, 2001).

Despite the resource problems encountered by most parastatals, a few parastatals have come into significant amounts of money as a result of partial privatisation or corporatisation. Rather than leave these resources in the hands of the organisations being privatised to fund their transition to market-oriented enterprises, governments have appropriated the bulk of the resources. In fact, in many cases one of the primary reasons for undertaking privatisation has been to increase flows to the government exchequer, often to settle government debts or embark on some other favoured government program. For those parastatals whose resources have not been appropriated by the government the challenge has been how to spend the windfall prior to it disappearing under a flurry of claims made by various stakeholders. Many have embarked on paths of diversification and acquisitions. Given their limited competencies and experience in the business world, it is not surprising that such forays have created major problems and have had only limited success.

From the above, it becomes evident that most firms attempting transformation are caught between the traditional and "business" mode resource acquisition logic. While the business mode resource acquisition logic increases the probability of long-term financial viability (assuming the transformation is successful) it also raises the probabilities of disappointments and mortality risk (Singh, House and Tucker, 1986; Hambrick and D'Aveni, 1988). Such a calculus increases resistance to divergent change and transformation.

\subsection{Workforce}

Dealing with requisite changes in the workforce is very often one of the greatest challenges facing recently privatised firms as they embark on strategic transformation. Given their history, these organisations very often have a significantly larger work force than can be supported under free market conditions. Generally, this workforce lacks the competencies necessary for competing in the free-market mode. Rationalisation of the workforce downsizing the existing workforce and hiring new employees with the appropriate competencies - is thus critical for transitioning to the business archetype. Clearly transformation challenges organisational members' self-identity and meaning and creates high uncertainty about future roles and privileges which triggers anxiety (Argyris, 1990). A 
specific element that creates high anxiety as the organisation moves toward the market mode is the anticipated enactment of a new psychological contract where the employees are not guaranteed a job but the employers provide opportunities for employees to develop a broad range of competencies to ensure their employability though not necessarily in their current organisation. Not surprisingly there is resistance to such an attempt with most employees preferring to remain in the statist archetype mode where there was a measure of certainty with respect to their welfare.

In addition to creating ongoing operational problems for the firm undergoing transformation such resistance has an additional effect, i.e. it deters new employees with requisite competencies from seeking employment with the organisation as they become increasingly sceptical about the firm succeeding in moving to the market mode.

\subsection{Organisational Configuration}

State/public owned enterprises and organisations that were highly regulated had many of the characteristics of organisational configurations that Mintzberg (1979) labelled as machine bureaucracies. These organisations, particularly those in socialist countries, were designed for stability not change (Babic, 2001). Though the founding objectives of such configurations were appropriate, i.e. increase accountability to the public, reduce nepotism and establish clear career paths, these enterprises rapidly deteriorated into low-performing organisations with increased emphasis placed on maintaining ongoing processes and the current mode of functioning rather than recognising that these were a means to an end. As a result organization became rigid and hierarchical. Rather than focusing on customer needs, the superordinate goal of these organisations was to satisfy non-market demands, whether they were those of central planners, state agencies or regulators. Not surprisingly, these configurations became totally unsuitable for functioning in a market economy, viz. they are not fluid or agile enough to meet the demands of market-based competition and the interests of various stakeholders. Despite this unsuitability, few organisations and their managers have recognised the problems that their organisational configurations have created. Such ossification and entrenchment creates great difficulties in moving toward organisational configurations that are more appropriate for functioning

One could legitimately argue that the challenges described above are not exclusive to the parastatals but are indeed common to all organisations undergoing major transformations. The very nature of the parastatals, however, ensures that they are not. First, the challenge that they face is quite unique as these organisations have not had a repertoire of dealing with challenges of this nature in the past as would generally be true of firms that have historically functioned in a market economy. Secondly, given various pressures to return to their traditional mode of functioning, the time available for the transformation is rather limited.

In order to test the validity of these perspectives we examined attempts at strategic transformation in three major Estonian organisations (brief profiles provided in "The Study" Section) in the infrastructure sector: Eesti Gaas, Eesti Energia, and Eesti Telefon ${ }^{1}$. We focused on the firms in the infrastructure sector because of their size and importance in the overall Estonian economy and their different levels of privatisation. We were also convinced that they would provide a better test of the validity of our perspectives than small and mid-sized firms. While there have been a number of studies that have examined the privatisation process in Estonia along with the shift of the macro economy from statist to a market based one (Terk, 2001 provides a good overview), there has not been any systematic study to date that has examined the actual process of transformation within organisations. We start by providing a brief overview of privatisation in Estonia and follow this up with our study of strategic transformation. Also, as organisational transformation is a complex phenomenon, and the full consequences of the transformation have not yet become evident - given the limited time that has elapsed since the start of the transformation process our study will focus only on the dynamics of the transition.

\subsection{Privatisation in Estonia}

Arguably one of the greatest and most successful transitions from a socialist economy to a market-based economy took place in Estonia through the decade of the nineties. In early 2000's transformation efforts have put Estonia in frontline of countries joining EU in 2004. Contrary to the mass privatisation model adopted in Russia and some other Baltic and Eastern European states, or the employee buy-out of assets adopted, for example, in Poland 
and Belarus, the model employed in Estonia was the selling of the majority control of the enterprise to an outside investor, often a foreign company.

In the middle of the 1980s, private ownership and entrepreneurship were practically non-existent in Estonia. The first tentative steps toward private ownership reform occurred when new small (state owned) companies and privately owned co-operatives were allowed at the end of the eighties though the co-operatives were warned not to "exploit their employees". The privatisation process - auctioning of small business - started in earnest in March 1991 following the passage of the Law on Small Scale Privatisation in 1990. In the second half of 1991, the municipalisation of state property was started and applications for the restitution of private property began. Entrepreneurial Estonians pushed the boundaries of these rules and government institutions and undertook various forms of "spontaneous privatisations". A series of laws on Fundamentals of Ownership Reform, Land Reform and Bankruptcy were then passed to ease the privatisation process prior to the passage of the comprehensive Privatisation Law in June 1993. The passage of these laws set the stage for full-scale privatisation. An independent agency, the Estonian Privatisation Agency (EPA) was established to manage the privatisation process. It was decided to adopt the German Treuhand model for privatising medium and large-scale units. There was broad consensus to speed up the privatisation process not only to prevent any resistance from building up but also to establish an identity in the increasingly crowded East European privatisation market. An additional benefit was that speedy implementation could help prevent unauthorised dispositions of state property.

The primary aim of the privatisation process was not to maximise revenues for the treasury or political expediency (as in Russia) but to increase the long-term economic growth potential for the country. The process relied on international public tenders and offers were judged on the basis of business plans that outlined future investments, employment goals and the qualifications of investors in addition to their financial resources. Foreign strategic investors were cultivated for participation in key sectors of the economy in order to drive the rapid adoption of corporate governance practices. By the end of the decade, over $80 \%$ of state owned companies had been privatised and over $80 \%$ of the revenues of the business revenues came from the private sector. Also, firms that had capital infusion from foreign sources generated more than $50 \%$ of Estonian exports.

The success of the privatisation process has been attributed to the transparency of the process, the level of trust developed by investors in dealing with the EPA and the widespread political consensus for privatisation. Having successfully completed the privatisation of most of the medium and large enterprises by 1998 the government turned its attention to the more difficult task of privatising infrastructure companies.

\subsection{The Study}

\subsection{The Firms in the Study}

The focal organisations for the study were three infrastructural firms: Eesti Gaas, Eesti Energia, and Eesti Telefon as a part of the Estonian Telekom group.

1. Eesti Gaas transports and sells natural gas and installs and maintains a gas distribution network. When Estonia was part of the Soviet Union, Eesti Gaas was directly subordinated to Moscow. Eesti Gaas was founded as a state office in 1988 and was converted to a state owned enterprise on January 1, 1991. After Estonia regained its independence there was confusion regarding the Eesti Gaas' ownership, whether the Russian company that built the network or the Estonian state owned enterprise - Eesti Gaas - that was operating the network. The Estonian government sought to remedy this situation by offering a $30 \%$ equity stake to Gazprom, the successor to the company that had originally built the network of gas pipelines. Following the clarification of ownership, privatisation of Eesti Gaas was conducted in stages. Today Eesti Gaas' shareholders include OAO Gazprom (Russian): 37.02\%; Ruhrgas AG (German): 33.31\%; Fortum Oil and Gas $O Y$ (Finnish): 17.72\%; Itera Latvija: 9.71\% and the remaining 2.24\% being held by dispersed investors.

Following privatisation, the bulk of the new investments were made to increase the reliability and efficiency of the pipeline network (operational improvements), improve gas metering for residential households 
(revenue enhancements) and to make gas available to new clients (market development). These investments approximated 20 million kroons annually between 1993 and 1997.

In 1997, Eesti Gaas consisted of six different companies: Eesti Gaas (Headquarters) and five subsidiaries in five different locations in Estonia. Each subsidiary was responsible for the sales of gas in its respective geographical region.

2. Unlike Eesti Gaas, which has been fully privatised, Eesti Energia is still owned by the state. The transmission and distribution facilities of Eesti Energia were, however, separated from power generation and partly privatised; simultaneously, according to the Energy Act, large Estonian customers were allowed to buy electricity from neighbouring countries such as Latvia and Lithuania. Despite these developments complete privatisation of Eesti Energia has probably been constrained by strong pressure from the general public not to raise tariffs and the need to increase operational efficiency.

3. Eesti Telefon was fully owned by the state till 1 January 1993. At this time a new entity Eesti Telekom was established and Eesti Telefon was partly privatised. Later, from 1999 Eesti Telekom was listed on both London and Tallinn stock exchanges. $49 \%$ of the equity of Eesti Telekom is held in equal proportions by Telia AB (a Swedish Telecom operator) and Sonera OY (a Finnish telecom operator, today, after merger Telia-Sonera) with the remainder of the equity being owned by the state of Estonia (27.3\%) and public investors (23.7\%). Eesti Telefon is now a wholly owned subsidiary of Eesti Telekom. Eesti Telefon was guaranteed exclusivity local and long distance communications till 2001 at which time the market was to be open to competition.

\subsection{Data Collection}

Data gathering commenced in early 2000 at around the time infrastructure privatisation was commenced in earnest by the Estonia Government and lasted through the end of 2000 by which time key decisions had been made with respect to privatisation. A team of researchers working with one of the authors interviewed senior managers (including the CEO/Managing Director) of the firms analysed in the study. As can be seen from the English version of the interview guide (see Appendix I) the questions were designed to gain insight into management thinking as they embarked on the privatisation process. Five to seven managers were interviewed in each firm. Interviews were adopted as the primary mode for gathering data as many of the concepts and issues were alien to the interviewees and the presence of interviewers was necessary to clarify these. As all interviewers were native Estonian speakers this was not a problem. Only those findings on which there was consensus among the interview team members are reported below.

\subsection{Findings}

\section{Strategic Orientation}

Contrary to the situation in many other transitioning economies, senior managers in all three firms studied were relatively quick to generate new missions and goals that were consistent with operating in market-space. This was partly due to the fact that establishing a market-economy, transitioning away from the socialist central planning system, and adopting a Western ideology was seen as the best option to assert Estonia's independence. Estonians had never embraced being part of the USSR and establishing "Western" credentials rapidly overcame any lingering benefits derived from the old ideology and system. Additionally the managers realised rather quickly that there was a window of opportunity for them to control their own destiny by proactively moving toward market-space. As speedy transformation was seen as of the essence, the implicit mission adopted by all three firms was to transform their organisations to be more customer-focused and compete in a market economy. Pro-transformation managers were also convinced that the market would not tolerate the level of inefficiencies that had been tolerated under the centrally planned regime. Hence "improving efficiency" was rapidly adopted as the superordinate goal. Given the perception that transition toward a market based economy would facilitate integration with Western economies and reinforce independence from the East, Estonians were quick to adopt Western institutional frameworks that would 
provide impetus to the transformation. Rejecting voucher based privatisation as had been adopted in Russia and adopting the German Treuhand facilitated the process and increased trust and confidence in Western investors who would have to play a key role in providing support and resources to move toward the market economy.

The situation was a bit different with respect to the task environment. Lack of familiarity with competing in a market economy and lack of market-oriented competencies meant that all three firms studied were operating in the dark. Through a trial and error process and with some technical support from foreign companies that had bought a strategic stake (Rurhgas, Fortum, Telia, Sonera etc.) the companies were able to gradually move toward the market orientation. Given their relative importance, managers focused attention on their larger customers who

The Treuhand privatisation model adopted by Estonia and the manner in which the bids were accepted led to a focus on enterprise value. Managers realised that enterprise value could only be maximised if they were able to generate interest and resources from foreign investors. This was in contrast to Russia where the voucher based privatisation program enabled many entrenched managers and their cronies to amass significant value for themselves at the expense of the organisation or the state.

Interestingly, while recognising the importance of being market/customer oriented cognitively, organisational members found it difficult to accept and execute this orientation in practice. A significant reason for this was that there was no heritage of customer orientation in these organisations, which had been dominated historically by technical personnel. Not surprisingly, these personnel saw the market orientation as being a significant threat to their power and influence and engaged in long contentious debates about the appropriateness of customer orientation. Given the pervasive fear of layoffs, even those organisational members who had accepted the notion of being more customer-oriented found it difficult to make their case. Lack of market-oriented competencies within the organisations compounded the difficulties of the transition. However, as customer demands increased and there was talk of opening up the infrastructure sector to competition, resistance to developing a market/customer orientation started to diminish. Resistance diminished further as vocal opponents to market-space transformation were laid off as part of the process of improving efficiencies. This permitted the more progressive, protransformation oriented employees and new hires to be the catalyst for the transformation. By setting an aggressive agenda they created a measure of certainty for straddling organisational members.

\section{Resource Acquisition Logic}

With the market orientation thrust being driven by the drive for political independence it soon became clear to the management of Eesti Gaas, Eesti Energia and Eesti Telekom that the level of support from the state would rapidly approach zero. The transformation and survival challenge was compounded by the fact that these firms were to be at the tail end of the privatisation process (perceived as more risky by investors) and their ability to raise rates etc. was likely to be limited given their key role in the economy. This soon convinced management that the only way they could obtain resources was to rationalise their operations and reduce costs. The fact that efficiency improvements would aid in attracting resource rich foreign investors was a bonus. Being at the tail end of privatisation was also beneficial in that they would not have to face immediate aggressive competition in the short run as even if the economy as a whole was opened up it would take some time for private firms to have the necessary assets and structure in place. The local and long distance fixed line monopoly till 2001 that was given to Eesti Telekom was critical in generating resources that were needed to cope with the rapidly changing technology in telecommunications. In order to position itself to deal with ensuing competition and make it attractive to investors or strategic partners, Eesti Telekom invested very extensively in digitalisation, Internet infrastructure including ADSL and a multitude of new products and services.

\section{Workforce}

As discussed in the previous two sections, there was strong pressure to increase operational efficiency in all three firms studied. Given their communist heritage, there was considerable excess employment in all three units and rationalisation was going to be inevitable. Additionally much of the workforce lacked the competencies (customer focus, pricing and yield management, innovation etc) that were likely to be critical in competing successfully in a market-based economy. Not surprisingly, the transformation process created a lot of anxiety and 
resistance. However, it soon became clear to the work force that there was no choice and given the political underpinnings of the macro-transformation process (sustaining political independence) there was really no going back. On the competency front the biggest challenge faced by management in all three companies was making the workforce realise that resources could only come from the market and being sensitive to client expectations and developing a financial understanding of the situation. Management attempted to build up these competencies within the workforce but creating deep change in the mindset of most of the organisational members has proven to be a daunting task.

Despite the overwhelming pressure to increase efficiency, an area that management has been relatively slow to target is outsourcing - a trend that is gaining prominence in most established market economies. In our judgement this was a very judicious decision, as increasing outsourcing would have increased anxiety, hurt employee morale and made the transition toward a customer oriented culture more difficult.

\section{Organisational Configuration}

In the past Eesti Telekom and Eesti Energia had been organised around a territorial/regional structure where the regional units had broad autonomy. As part of the rationalisation process, and to be more customer focused, these firms moved toward a functional, flatter configuration. In contrast Eesti Gaas maintained more of a regional structure with entities in different regions being organised as regional centres. Eesti Telekom and Eesti Energia have also started adopting a more process-oriented approach in order to reinforce the customer orientation and reduce the strain toward functional autonomy that is characteristic of functional structures.

\subsection{Concluding Remarks}

While it is too early to state that the transformation process has been successful in terms of moving the organisations fully into market space, there is no doubt that in the short-term that transformational processes have been underway, the firms are well on their way toward developing an orientation that is appropriate for functioning in a market economy. The transition period has bee longer than in similar cases in free-market countries, but shorter than in most, if not all, transition economies. Senior managers have been sensitive to the changes in ideologies and business contexts that this transformation entails and have developed a clear vision and goals consistent with this vision. While the pace toward achieving the customer-orientation, and a willingness to compete aggressively in the market place, has probably not been at the desired level there is no denying the fact that such an orientation is in fact being developed. A huge difference has been made in strategic thinking and operational excellence, customerorientation and readiness to change. It is noteworthy also that today all three companies are making profits. This progress is all the more laudatory when one considers that the required shift in orientation necessitates significant amounts of unlearning. Clearly, the transformational process was facilitated by the drive to regain independence, and gain accession to the EU as quickly as possible. There was simultaneous "Eastern push" and "Western pull". In our judgement probably the most important factor to cause these formerly centrally planned organisations to tip to the free-market model was the legitimacy created by a number of former socialist/ communist/centrally planned economies that were also in the process of transforming themselves. Were this not so it would have enabled opponents of the transformation process to mobilise and delay, if not torpedo the process. Clearly managers from all three firms studied were able to strike the balance between competing claims and pressures and move the transformation forward. This is a lesson on successful vision-driven strategic transformation for anyone.

\section{References}

1. Amburgey, T., D. Kelly and W.P. Barnett. (1993). "Resetting the Clock: The Dynamics of Organizational Change and Failure." Administrative Science Quarterly, 38: 51-73.

2. Argyris, C. (1990). Overcoming Organizational Defenses. Boston, MA: Allyn and Bacon.

3. Argyris, C. and D. A. Schoen. (1978). Organizational Learning. Reading, MA.: Addison-Wesley.

4. Baliga, B.R., and James G. Hunt. (1987). “An Organizational Life Cycle Approach to Leadership.” In Hunt et al., (Eds) Emerging Leadership Vistas. Lexington, MA.: Lexington Books.

5. Bartlett, C.A. and S. Ghoshal. (2000). Transnational Management (Third Edition), N.Y., N.Y. McGraw Hill. 
6. $\quad$ Bass, B.M., B.J. Avolio and L. Goodheim. (1987). "Biography and the Assessment of Transformational Leadership at the World Class Level." Journal of Management, 13:7-20.

7. Best, M. (1990). The New Competition, Cambridge, MA: Harvard University Press.

8. Bettis, R. and C.K. Prahalad. (1995). "The Dominant Logic: Retrospective and Extension." Strategic Management Journal, 16.1: 5-14.

9. Burawoy, M. and J. Lukacs. (1992). The Radiant Past: Ideology and Reality in Hungary's Road to Capitalism. Chicago: University of Chicago Press.

10. Child, J. (1972). "Organizational Structure, Environment and Performance: The Role of Strategic Choice." Sociology, 6:1-22

11. Child, J. and L. Markoczy. (1994). "Host Country Managerial Behavior in Chinese and Hungarian Joint Ventures: Assessment of Competing Explanations.” In M. Boisot (ed.) East-West Business Collaboration. London: Routledge.

12. Clarke, L. (1994). The Essence of Change. Hertfordshire: Prentice-Hall.

13. DiMaggio, P. and W. Powell. (1983). "The Iron Cage Revisited: Institutional Isomorphism and Collective Rationality in Organizational Fields.” American Sociological Review, 48: 147-160.

14. Kelly, D. and T. Amburgey. (1991). "Organizational Inertia and Momentum: A Dynamic Model of Strategic Change." Academy of Management Journal, 34: 591-612.

15. Kokh, A.R. (1998) The Selling of the Soviet Empire: Politics \& Economics of Russia's PrivatizationRevelations of the Principal Insider, SPI Books.

16. Guillen, M.F., (2001). The Limits of Convergence, Princeton, N.J.: Princeton University Press.

17. Hambrick, D.C. and R. D'Aveni. (1988). "Large Corporation Failures as Downward Spirals." Administrative Science Quarterly, 33:1-23.

18. Hitchens, D. W., J.E. Birnie, J. Hamar., K. Wagner and A. Zemplinerova. (1995). Competitiveness of Industry in the Czech Republic and Hungary. Aldershot: Avebury.

19. Lant, T.K. and D.B. Montgomery. (1987). "Learning from Strategic Success and Failure." Journal of Business Research, 15:503-517.

20. Lazonick, W. (1991). Business Organization and the Myth of the Market Economy. Cambridge: Cambridge University Press.

21. Lazonick, W. and J.West. (1995). "Organizational Integration and Competitive Advantage: Explaining Strategy and Performance in American Industry." in Industrial and Corporate Change, 4/1: 229-270.

22. McMillen, A.F. (2001) India Shelves Airline Sale in Privatization Push, October 30. CNN.com/Business.

23. Meyer, A., G. Brooks and J. Goes. (1990). "Environmental Jolts and Industry Revolution." Strategic Management Journal, 11 (Summer): 93-110.

24. Mintzberg, H. (1979).Structuring of Organizations, Englewood-Cliffs, N.J., Prentice-Hall

25. Nelson, R. and S. Winter. (1982). An Evolutionary Theory of Economic Change. Cambridge, MA: Harvard University Press.

26. Ocasio, W. (1994). "Political Dynamics and the Circulation of Power: CEO succession in U.S. Industrial Corporations, 1960-1990." Administrative Science Quarterly, 39: 285-314.

27. Ocasio, W. (1997). "Toward an Attention Based View of the firm." Strategic Management Journal, 18: 187-206.

28. Ocasio, W. (1999). "Institutional Action and Corporate Governance: The Reliance on Rules of CEO Succession.” Administrative Science Quarterly, 44: 384-416.

29. Powell W. and Paul J. Dimaggio. (1983). The New Institutionalism of Organizational Analysis. Chicago: University of Chicago Press.

30. Singh. J.V.R., R.J. House and D.J. Tucker. (1988). "Organizational Change and Organizational Mortality." Administrative Science Quarterly, 31:587-611.

31. Terk, Erik. (2001) Privatization in Estonia. Tallin: Eesti Tuleviku-uuringute Instituut.

32. Tushman, M.L. and E. Romanelli. (1987). "Executive Succession, Strategic Reorientation and Organizational Evolution.” Technology in Society, 7:297-314.

33. Whitley, R., J. Henderson, L. Czaban and G. Lengyel. (1996). "Continuity and Change in the Emergent Market Economy." in R. Whitley and P. Kristenson, The Changing European Firm. London: Routeledge. 


\section{Appendix I \\ Interview Guide}

Mission and Goals

1. Who initiated development of the new mission?

2. What was the reaction of the organizational members to the development of the new mission?

3. What factors were considered in the development of the new mission?

4. How much time did top management feel they had to make the transformation?

5. Were specific goals and objectives set? What were these?

Assessment of the Environment

1. What was top managements' assessment of the changing environment?

2. Did they believe that changes were real? Did they feel overwhelmed?

3. Did they feel that the environmental changes would ultimately be positive or negative for the organization?

4. What impact did the presence or absence of an institutional infrastructure play or not play in the transformation?

Ownership Considerations

1. Whose interests did management feel they had to consider most: (a) themselves, (b) their employees or (c) new owners -if different?

2. What did they consider to be the prime role they had to play in the transformation of the enterprise?

3. If partners were involved what role did they play in the transformation process?

Customers

1. Did management see their customers as being difference? Did they classify their customers in those that were (or could be) more profitable or those who had to be subsidized?

2. Did management feel that they had to treat their customers differently? i.e. did they feel that they had to pay more attention to their profitable customers?

3. What was the attitude of employees toward customer service? Did they feel that their customers were placing increasing/unfair demands on them?

\section{Workforce}

1. Did management start to see their workforce more critically? Did they feel that the workers were lazy and did not have the necessary competencies?

2. How did they consider getting rid of the "excess" workforce?

3. How soon did they feel they had to rationalize their work force?

4. Did they regret having to rationalize the work force (if so undertaken)?

5. Did management see the movement toward a more business like organization and emphasis on productivity Mindset as being positive or negative?

1. Did management and key employees have difficulty in moving toward the "market" mindset?

2. Did management feel comfortable moving in the new direction?

3. Did management feel comfortable with "profitability" considerations after so many years of considering profits to be undesirable to exploitive?

Internal Structure and Processes

1. What organizational elements did management feel they had to deal with quickly?

2. What processes were put in place to move the organization toward the market mode?

3. Did management benchmark other firms?

4. What role did non-Estonian people or firms play in helping redesign the new processes and structures?

5. If partners were involved, what role did they play in helping transform the internal structure and processes? 


\section{Notes}


